\section{Reorganisation of Earth's biogeochemical cycles briefly oxygenated the oceans 520 Myr ago}

\section{T.W. Dahl ${ }^{1 *}$, J.N. Connelly ${ }^{1,2}$, A. Kouchinsky3} B.C. Gill ${ }^{4}$, S.F. Månsson ${ }^{1}$, M. Bizzarro ${ }^{1,2}$

\section{Abstract}

The Phanerozoic radiation of bilaterian animals has been linked to oxygenation of Earth's oceans, due to the oxygen demand of the evolving animal ecosystems. However, how early animals may have ryguted Earth's surface oxygen budget via self-stabilising feedbacks is poorly understood. poorly understood. Here, we report parallel positive uranium, carbon, and sulphur isotope pexcursion episode 521-520 Myr ago, at the onset of diversification of larger arthropods known from the fossil record. Our data and model indicate that an abrupt increase in the sinking rate of marine organic matter expanded the oxygenated zone in the oceans and that reducing conditions returned $1.3 \pm 0.8 \mathrm{Myr}$ after the onset of this transient oxygenation episode, necessitating a strong negative feedback to the increasing levels of oxygen. We speculate that larger zooplankton could have sourced both oxygen and food to the seafloor, fueling bioturbation over wider areas and, thereby, stabilising $\mathrm{O}_{2}$-rich habitats in the oceans. Thus, this reorganisation exemplifies how animal ecosystems might have influenced oxygen availability in Earth's surface environment soon after their establishment.

Received 13 December 2016 | Accepted 15 May 2017 | Published 15 June 2017

\section{Letter}

In contrast to many geochemical proxies that evaluate local ancient marine redox including iron speciation and trace metal (Mo, U, V) enrichments, the uranium isotope composition $\left(\delta^{238} \mathrm{U}\right.$, the per mille deviation of the ${ }^{238} \mathrm{U} /{ }^{235} \mathrm{U}$ ratio relative to CRM 145 standard) of seawater can be used to evaluate ocean oxygenation at

\footnotetext{
1. Natural History Museum of Denmark, University of Copenhagen, Denmark Corresponding author (email: tais.dahl@snm.ku.dk)

Centre for Star and Planet Formation, University of Copenhagen, Denmark

3. Swedish Museum of Natural History, Stockholm, Sweden

Virginia Polytechnic Institute and State University, Blacksburg, USA
}

a globally integrated scale. This is possible due to the long residence time and uniform $\delta^{238} \mathrm{U}$ of uranium in the modern ocean and predicted for the Cambrian ocean (Weyer et al., 2008; Dahl et al., 2014; Tissot and Dauphas, 2015). The $\delta^{238} U$ proxy has been utilised to track past global ocean redox during three known oceanic anoxic events (Montoya-Pino et al., 2010; Brennecka et al., 2011; Dahl et al. 2014; Elrick et al., 2016; Lau et al., 2016), where anoxic water masses expanded over larger areas of the seafloor and caused negative $\delta^{238} U$ excursions. Here, we use uranium isotopes to identify a transient global oxygenation episode during the radiation of animals in the Cambrian.

Our new $\delta^{238} U$ data of carbonate-associated uranium comes from limestones collected from the Siberian Platform across the provisional Cambrian Stage $2-3$ boundary ( 521 to 520 million years ago) (Fig. 1), when animals that shed their exoskeleton (ecdysozoa) began to diversify (Maloof et al., 2010; Kouchinsky et al., 2012). A perturbation in the marine carbon cycle is expressed at this time as a large positive carbon isotope excursion recognised globally and in all studied sections; geological maps and stratigraphic sections are shown in Figures S-1 and S-2 (Maloof et al., 2010). This excursion serves as an important stratigraphic marker, although little is known about the biogeochemical significance of the event. The end-Stage 2 samples carry low $\delta^{238} \mathrm{U}$ values of $-0.65 \%$ o, increasing stratigraphically to a value of $-0.45 \%$ o that approaches the modern oxygenated oceans, $-0.39 \pm 0.01 \%$ o (Tissot and Dauphas, 2015), before again returning in two steps to $-0.7 \%$. This positive $\delta^{238} \mathrm{U}$ excursion of $+0.25 \%$ coincides with the positive carbon isotope excursion, suggesting that they are both linked to the changes in global seawater chemistry. The samples display no systematic correlation between the $\delta^{238} \mathrm{U}$ excursion and indicators of dolomitisation $(\mathrm{Mg} / \mathrm{Ca}$, dolomite), pore water redox conditions (total organic carbon content), diagenetic alteration $\left(\mathrm{Mn} / \mathrm{Sr}, \delta^{18} \mathrm{O}\right)$ detrital input ( $\mathrm{Al} / \mathrm{Ca}$, clay content) and primary carbonate mineralogy ( $\mathrm{Sr} / \mathrm{Ca}$; see Supplementary Information S2) that might produce such a positive $\delta^{238} \mathrm{U}$ excursion, offset from contemporaneous seawater. That said, our samples consist of (abiotic) micrite with (biotic) shells made of secondary calcite (Fig. S-3). The difference between abiotic and biotic precipitation of calcite $\delta^{238} \mathrm{U}$ is predicted to induce a $\sim 0.1 \%$ offset from seawater (Chen et al., 2016). As we cannot determine the ratio of $U$ derived from abiotic to biotic sources, we conclude that at this level of confidence, an overall positive $\delta^{238} \mathrm{U}$ trend is observed in the stratigraphy that we ascribe to secular changes of open marine $\delta^{238} \mathrm{U}$ in early Cambrian seawater. We note that our data set is limited to only one section and predict the same trend can be observed in other marine deposits with authigenic $U$ enrichments.

The positive excursion of seawater $\delta^{238} \mathrm{U}$ represents a global oxygenation period in the oceans that dramatically decreased the fraction $\left(f_{U}\right)$ of total $U$ burial occurring in anoxic marine settings. A simple isotope mass balance calculation constrains $f_{U}$ from the $\delta^{238} U$ of seawater $\left(\delta_{S W}\right)$ (see derivation in Supplementary Information S4). This calculation assumes an isotopically constant $\mathrm{U}$ input from rivers and a constant isotope fractionation between seawater and the U sinks. The modern ocean is at steady state with $\delta^{238} \mathrm{U}$ at $-0.39 \pm 0.01 \%$ and estimates 
Global ocean deoxygenation

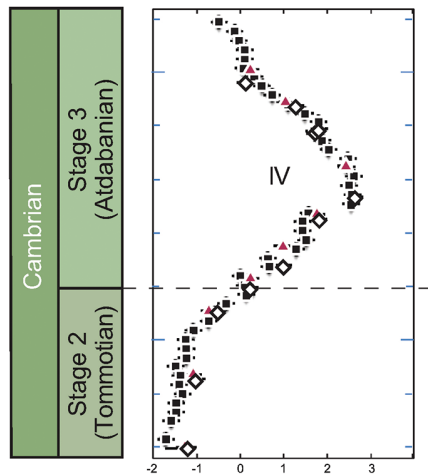

$\delta^{13} \mathrm{C}_{\mathrm{CARB}}(\% \mathrm{o})$

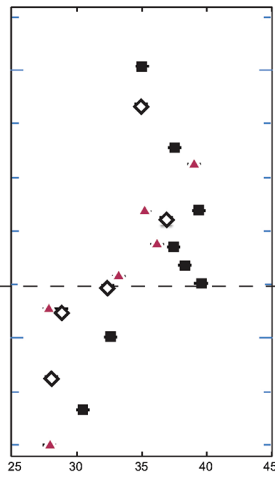

$\delta^{34} S_{\text {CAS }}(\%)$

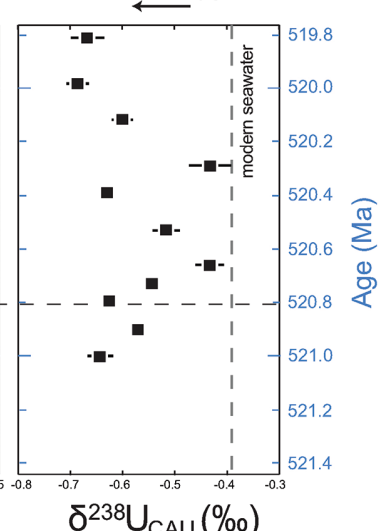

$\delta^{238} \mathrm{U}_{\mathrm{CAU}}(\%)$

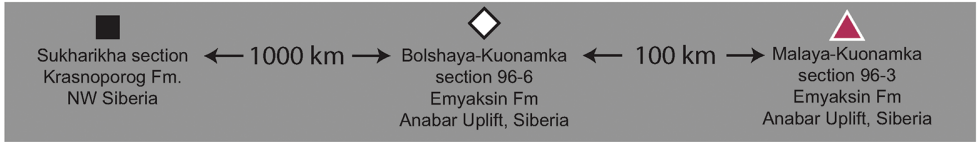
Figure 1 Isotope data from three carbonate successions straddling the Cambrian Stage 2-3 taken from Kouchinsky et al. (2007). Sulphur and uranium isotope data are from carbonateassociated sulphate $\left(\delta^{34} S_{C A s}\right)$ and uranium $\left(\delta^{238} U_{C}\right)$ respectively. Age assignments derived

for the average oceanic input range from $-0.30 \%$ to $-0.27 \%$ (Tissot and Dauphas, 2015; Noordmann et al., 2016). If the anoxic proportion of global U burial ( $\mathrm{f}_{\mathrm{U}}$ ) today is 12-25 \% (Morford and Emerson, 1999; Dunk et al., 2002; Noordmann et al., 2016), and anoxic settings impart a $+0.5 \pm 0.1 \%$ net isotope offset from overlying seawater, this implies that the average isotope fractionation between seawater and all other oxic U sinks $\left(\Delta_{\text {OTHER }}\right)$ is $-0.02 \pm 0.05 \%$. Given this formulation, we calculate that $68 \pm 18 \%$ of marine $U$ burial before the Stage $2-3$ event occurred in anoxic parts of the oceans when $\delta^{238} U$ of seawater was $-0.65 \%$. This scenario compares to the ocean state during the anoxic expansion associated with the end-Permian extinction (Brennecka et al., 2011). Further, the anoxic U burial fraction declined to $29 \pm 12 \%$ at the peak of the event and then afterward returned to a more reducing ocean state with $78 \pm 20 \%$ anoxic U burial (Fig. S-2). The stated uncertainties for $\mathrm{f}_{\mathrm{U}}$ in the Cambrian are propagated errors from $\Delta_{\text {OTHER, }} \Delta_{\text {ANOX, }}$ and $\delta_{\text {IN }}$ reflecting a range of plausible parameterisations of the marine U cycle (see sensitivity analysis in Supplementary Information S4 for details). These data consistently require the Cambrian Stage $2-3$ event to have occurred when the oceans were far more reducing than today, culminating at an oxygenation state similar to the modern ocean.

Existing palaeoredox studies also point to ocean oxygenation during the Early Cambrian (Fig. 2). Specifically, the molybdenum isotope $\left(\delta^{98} \mathrm{Mo}\right)$ record from shales and phosphorites show several fluctuations recorded in $\sim 560$ to 520 Myr old stratigraphic sections in China (Wille et al., 2008; Wen et al., 2011; Xu et al., 2012; Chen et al., 2015; Kendall et al., 2015; Wen et al., 2015). The last positive $\delta^{98} \mathrm{Mo}$ excursion is broadly correlated to the first appearance of trilobites in China, strong Mo enrichments and with the oxygenation event reported here (Dahl et al., 2010; Xu et al., 2012; Chen et al., 2015; Wen et al., 2015; Jin et al., 2016). The coincident positive $\delta^{98} \mathrm{Mo}$ and $\delta^{238} \mathrm{U}$ excursions point to a widespread oxygenation episode in the earliest Cambrian Stage 3 oceans where $\mathrm{O}_{2}$-rich waters expanded and affected the Mo and U isotope composition of seawater as the overall burial fluxes of Mo and $U$ into anoxic and euxinic settings decreased. We can predict the $\delta^{98} \mathrm{Mo}$ trajectory of seawater from the oceanic $\delta^{238} \mathrm{U}$ trajectory, if we assume the anoxic burial proportions of total Mo and $\mathrm{U}$ burial $\left(\mathrm{f}_{\mathrm{Mo}}, \mathrm{f}_{\mathrm{U}}\right)$ are correlated. We adopt a power law relationship $\mathrm{f}_{\mathrm{Mo}_{\mathrm{o}}}=\mathrm{f}_{\mathrm{U}}{ }^{\alpha}$ that satisfies $\mathrm{f}_{\mathrm{Mo}}=\mathrm{f}_{\mathrm{U}}=1$ during extreme anoxia and $\mathrm{f}_{\mathrm{Mo}}=\mathrm{f}_{\mathrm{U}}=0$ for extreme oxia. Using the modern ocean state as a calibration point, we find that $\alpha=1.34 \pm 0.38$ (see Supplementary Information for details). Based on this relationship, average seawater $\delta^{98} \mathrm{Mo}$ should have increased from $1.40 \%$ in the Cambrian Stage 2 to a peak at $2.0 \%$ o before returning to $1.10 \%$ during the $\delta^{238} \mathrm{U}$ excursion. This prediction is in good agreement with the maximum values observed in the $\delta^{98} \mathrm{Mo}$ record during this time interval (Lehmann et al., 2007; Chen et al., 2015; Wen et al., 2015) (Fig. 2). Collectively, the $\mathrm{Mo}$ and $\mathrm{U}$ isotopes indicate a transient, rather than a persistent change in ocean oxygenation at the beginning of Stage 3. This implies that earlier positive $\delta^{98}$ Mo excursions ( 2 \%o) in Terreneuvian phosphorite deposits (Wen et al., 2011), and perhaps in the latest Ediacaran (Kendall et al., 2015), represent episodic events rather than persistent ocean oxygenation. Similarly, detailed studies of the bottom water redox conditions in the Nanhua Basin, South China, suggest that oxygenated waters also invaded shallower part of the basin later in the Stage 3 (Jin et al. 2016). As such, the oxygenation history of the early Cambrian ocean appears more dynamic than previously thought (e.g., Dahl et al., 2010; Sperling et al., 2013; Chen et al., 2015).

The oxygenation event coincides with global changes in the marine carbon and sulphur cycles. We also report sulphur isotope data from carbonate-associated sulphate $\left(\delta^{34} S_{C A S}\right)$ from three distinct stratigraphic sections in Siberia that show a similar systematic positive $\delta^{34} S_{\text {CAS }}$ isotope excursion coinciding with the $\delta^{238} \mathrm{U}$ and $\delta^{13} \mathrm{C}$ excursions (Fig. 1). The simultaneous excursions across the Cambrian Stage 2-3 boundary suggest the C, S and U cycles responded to the same global biogeochemical event. Similar parallel positive carbon and sulphur isotope excursions during the late Cambrian SPICE event (Gill et al., 2011; Dahl et al., 2014) and the Botoman Sinsk event were interpreted to represent a period of enhanced organic carbon and pyrite burial (Zhuravlev and Wood, 1996). While these events are linked to expanding ocean anoxia and animal extinctions, the positive $\delta^{238} \mathrm{U}$ excursion reported here reveals a distinct driver for the environmental change. 


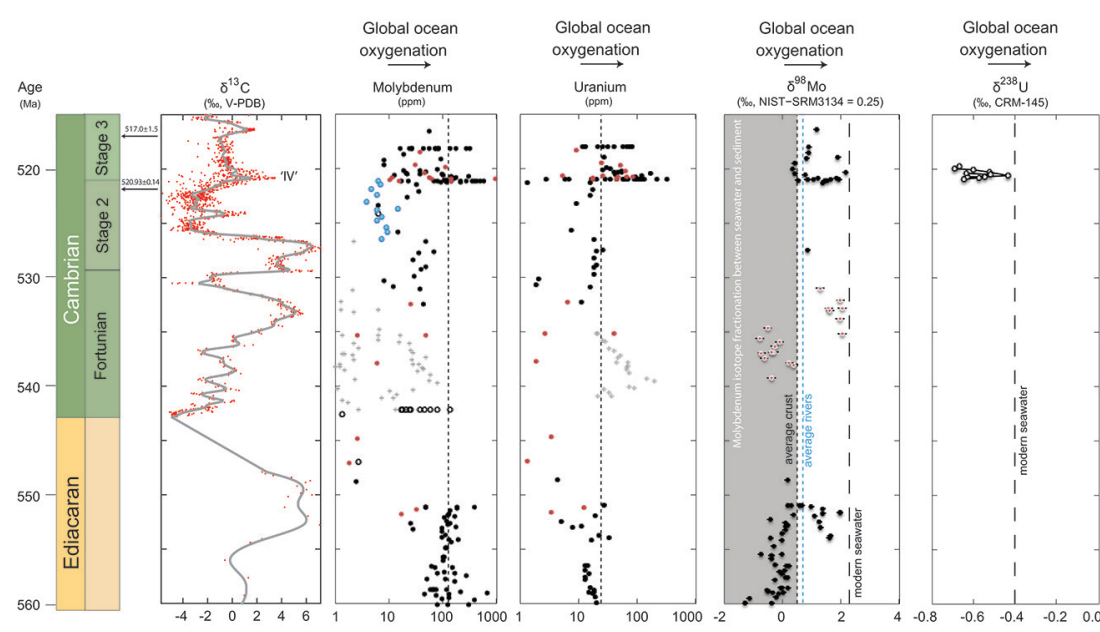

Figure 2 Summary of the redox proxy and carbon isotope data from latest Ediacaran to Early Cambrian ( isotope compositions of molybdenum and uranium: Euxinic shales (black circles), Ferruginous shales (red circles), oxic shales (blue circles), shales from unknown redox environments (gray crosses), phosphorites (white diamonds), and carbonates (white circles). The grey field on the molybdenum isotope plot indicates values that are definitively fractionated from seawater, although values greater than these may be so as well. References for the data are listed in the Supplementary Information Extended Data, Table S-22.

The Cambrian Stage 2-3 event coincides with the onset of the first major diversification of arthropods, which predates by a few million years the first appearance of macrozooplankton and suspension-feeding anomalocarids (Hou, 2004; Stein et al., 2009; Vinther et al., 2014). Therefore, we consider that this oxygenation episode reflects the first invasion of larger zooplankton in the pelagic zone that triggered an increase in the sinking rate and compaction of organic matter. Today, the export of organic matter from the photic zone ( $<200 \mathrm{~m}$ depth) - a process referred to as the biological pump - occurs as sinking molts, faecal matter, carcasses, and skeletons (Alldredge et al., 1993; Hedges and Keil, 1995) The sinking velocity of a particle in the ocean is a quadratic function of its size. Therefore, a small increase in the mean size of particulate organic matter would have caused the rates of water column remineralisation to decrease, so that less $\mathrm{O}_{2}$ was consumed in the water column and a more gentle $\mathrm{O}_{2}$ gradient was established below the photic zone (Fig. 3, Meyer et al., 2016). Consequently, more organic matter would have been exported to the seafloor resulting in enhanced rates of organic carbon and pyrite burial.

To quantify the potential consequences of faster sinking rates on organic carbon export (JRAIN) onto the seafloor, we utilise the $\delta^{13} \mathrm{C}$ and $\delta^{34} \mathrm{~S}$ data and a simple biogeochemical model for the coupled marine $C$ and $S$ cycles. Organic carbon export fuels both organic carbon burial (JORG $\left.=\mathrm{J}_{\text {RAIN }}-\mathrm{J}_{\text {REMIN }}\right)$ and

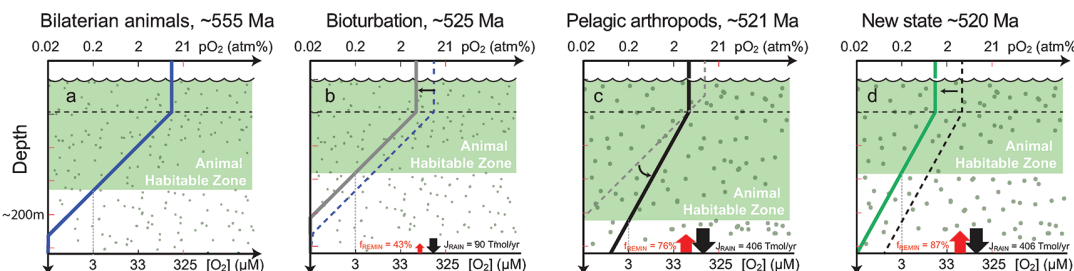

zone in the oceans. The emergence bil morian for atmospheric $\mathrm{pO}_{2}$ to decline. The oxygenation zone contracts until (c) a rapid increase in the sinking rate of organic matter changes $\mathrm{O}_{2}$ consumption rates in the upper water column. (d) This accelerates organic carbon export to the sediments and delivers more food and $\mathrm{O}_{2}$ to the benthos over wider areas of the seafloor. Enhanced bioturbation promotes atmospheric $\mathrm{pO}_{2}$ decline, and re-stabilises the ocean in a more reducing state. Arrows and numbers illustrate organic export fluxes in one scenario (details in Table S-11). For simplicity, the organic C export increases in one step with the emergence of larger faecal pellets. Quantitative estimates for organic carbon export and remineralisation are derived from the coupled C and S isotope modelling (see Supplementary Information S5).

remineralisation in sediments $\left(\mathrm{J}_{\text {REMIN }}\right)$. In this model, pyrite burial is proportional to the remineralisation flux $\left(J_{\mathrm{PY}}=\alpha \cdot \mathrm{J}_{\mathrm{REMIN}}\right)$ because microbial sulphate reduction accounts for the major part of organic remineralisation in sediments and a fraction of its byproduct, sulphide, reacts with available Fe compounds to form pyrite (see Supplementary Information for model details). With this formulation ( $\alpha$ constant), we find that a 3-6 fold increase in the organic carbon rain rate is sufficient to increase $\delta^{13} \mathrm{C}\left(0\right.$ to $3 \%$ ) and $\delta^{34} \mathrm{~S}$ (28 to $40 \%$ ) simultaneously. This can be achieved with only a 1.7-2.5 fold increase in the mean of the size distribution of sinking organic matter particulates, assuming similar density and shape for the particulates before and after the invasion of larger zooplankton. We consider this as a minimum estimate, if a greater portion of larger faecal pellets do not aggregate (Butterfield, 1997). However, it shows that even a modest size increase potentially influences the global biogeochemical cycles.

The evolutionary history of animals over the Neoproterozoic-Cambrian transition suggests a stepwise increase in their overall size and their digestive tracts, which would have enhanced the biological pump (Logan et al., 1995; Butterfield, 2009; Lenton et al., 2014). Biomarker evidence suggests a fundamental shift in the preservation state of marine organic matter with abundant faecal matter in sedimentary rocks younger than $\sim 517 \mathrm{Ma}$ compared to similar rocks older than $\sim 565 \mathrm{Ma}$ (Logan et al., 1995). Although the abundance of pelagic animal fauna through the Cambrian Stage 2-3 interval is not known, it is apparent that the maximum size of pelagic heterotrophic organisms and their digestive tracts increased by three orders of magnitude from the Ediacaran into the Cambrian. Heterotrophic consumers such as micro- and mesozooplankton (20-200 $\mu \mathrm{m})$ evolved in the latest Ediacaran (635-542 Ma) (Perrier et al., 2015). The fossi record indicates that animals of probable chaetognath affinity ('protoconodonts') a few millimetres in size or larger swam in the early Fortunian ocean ( $>535 \mathrm{Ma})$ 
and that large macrozooplankton (i.e. bivalved arthropod Isoxys) up to $45 \mathrm{~mm}$ had appeared in the earliest Stage 3 ( 520 Ma) (Ivantsov, 1990; Hou, 2004; Stein et al., 2009). However, it says nothing about when various types of zooplankton became ecologically important. Rather, we suggest that a stepwise increase in the size of zooplankton is a plausible trigger for the reorganisation of Earth's marine biogeochemical cycles and, consequently, the earliest Cambrian Stage 3 oxygenation episode. By implication, earlier steps in animal evolution may have also led to oxygenation events preserved in the geochemical record during the Ediacaran-Cambrian transition (see below).

Given that the geochemical evidence suggests that the Cambrian Stage 2-3 oxygenation episode was brief, a stabilising feedback must have acted to counterbalance marine oxygenation. Current models for the evolving biogeochemical cycles in the Cambrian have not included such a rapid feedback mechanism (Bergman et al., 2004; Berner, 2006). Evidence from bioturbation indices (Mangano and Buatois, 2014) and Earth system modelling (Canfield and Farquhar, 2009; Boyle et al., 2014) suggest that the Cambrian Stage 3 oxygenation episode occurred during an apparent atmospheric $p \mathrm{O}_{2}$ decline resulting from increased mixing of marine sediments by animals. Since the early Cambrian Stage $2(\sim 530 \mathrm{Ma})$ animals had evolved the ability to burrow deeper into sediments acting to lower marine $\mathrm{P}$ availability, organic productivity, organic carbon burial, and hence the main source of atmospheric $p \mathrm{O}_{2}$ (Boyle et al., 2014). The emerging larger pelagic fauna accelerated this feedback mechanism, since the enhanced biological pump would have both increased the food supply and food quality for benthic heterotrophic organisms and led to more fully oxygenated conditions in the water column below the photic zone, thereby opening new ecospace for sediment-mixing animals over wider areas of the continental shelves. Subsequently, this focusing of organic matter at the seafloor increased overall rate of bioturbation, organic carbon remineralisation and oxygen consumption over larger areas of the seafloor and, ultimately, a decline in atmospheric $p \mathrm{O}_{2}$ that again limited the size of the oxygenated zones in the oceans (Fig. 3). It is notable that for this sequence of feedbacks to respond over the time scale of the Cambrian Stage 2-3 oxygenation episode (1.3 $\pm 0.8 \mathrm{Myr}$ (Maloof et al., 2010), see calculation in the Supplementary Information), atmospheric $\mathrm{O}_{2}$ inventory must have been significantly smaller than today in order to produce an excursion of the right duration. We derive an order of magnitude estimate for the atmospheric $\mathrm{OO}_{2}$ level at the Cambrian Stage 2-3 boundary of between $4 \pm 2$ and $7 \pm 4$ atm \% from the duration of the falling limb isotope excursions, assuming the global burial rate of marine organic carbon was the same as today. We also assume that anoxia returns as atmospheric $p \mathrm{O}_{2}$ levels decline due to less organic carbon burial over the course of $\sim 1 / 4$ to $\sim 1 / 2$ the duration of the full $\delta^{13} \mathrm{C}$ excursion $(\sim 325 \pm 200$ and $\sim 650 \pm 400 \mathrm{kyr})$. This atmospheric $p \mathrm{O}_{2}$ estimate scales linearly with global organic carbon burial flux and requires that the acceleration of the biological pump (by faecal pellets) and the subsequent migration of the sediment-dwelling taxa are essentially instantaneous $(<<100 \mathrm{kyr})$. This atmospheric $p \mathrm{O}_{2}$ level is well above the metabolic need for some animals (Pasteur limit $\sim 0.2 \mathrm{~atm} \%$ ) (Mills and Canfield, 2014), but not sufficiently high to oxygenate the deep oceans permanently (Lyons et al., 2014) and it conforms with the idea that animal ecosystems could have become selflimiting in terms of determining the size of the habitable ecospace in the oceans (Sperling et al., 2013; Boyle et al., 2014).

\section{Acknowledgements}

We thank N. Jenson, T. Balic-Zunic, H. Almind and N.J.B. Kristensen (UCPH) for laboratory assistance, S. Bengtson (SMNH) for field assistance in 1996 with $\mathrm{AK}$, and T.J. Algeo, C. Li and one anonymous reviewer for insightful comments. Funding for this project was provided by a grant from the VILLUM Foundation (VKR023127) to TWD, and from the Danish Agency for Science, Technology and Innovation (grant number 12-125692) to JNC as well as grants from the Danish National Research Foundation (grant number DNRF97) and from the European Research Council (ERC Consolidator grant agreement 616027-STARDUST2ASTEROIDS) to MB. Fieldwork was financially supported by grants from the Royal Swedish Academy of Sciences (KVA), the Swedish Natural Science Research Council (NFR), and the Swedish Research Council (VR).

Editor: Liane G. Benning

\section{Author Contributions}

AK collected the samples. TWD conceived the idea, designed the study, interpreted the data and created the models. TWD, JNC, BCG, SFM and MB analysed the samples and wrote the manuscript with significant contributions from all co-authors.

\section{Additional Information}

Supplementary Information accompanies this letter at www.geochemicalperspectivesletters.org/article1724

Reprints and permission information are available online at http://www geochemicalperspectivesletters.org/copyright-and-permissions

Cite this letter as: Dahl, T.W., Connelly, J.N., Kouchinsky, A., Gill, B.C., Månsson, S.F., Bizzarro, M. (2017) Reorganisation of Earth's biogeochemical cycles briefly oxygenated the oceans 520 Myr ago. Geochem. Persp. Let. 3, 210-220. 


\section{References}

Alldredge, A.L., Passow, U., Logan, B.E. (1993) The abundance and significance of a class of large, transparent organic particles in the ocean. Deep Sea Research I 40, 1131-1140.

Bergman, N.M., Lenton, T.M., WATSON, A.J. (2004) COPSE: A new model of biogeochemical cycling over Phanerozoic time. American Journal of Science 304, 397-437.

BERNER, R.A. (2006) GEOCARBSULF: A combined model for Phanerozoic atmospheric O2 and CO2 Geochimica et Cosmochimica Acta 70, 5653-5664.

Boyle, R.A., Dahl, T.W., Dale, A.W., Shields-Zhou, G.A., Zhu, M., Brasier, M.D., CANFIELD, D.E., LENTON, T.M. (2014) Stabilization of the coupled oxygen and phosphorus cycles by the evolution of bioturbation. Nature Geoscience 7, 671-676.

Brennecka, G.A., Herrmann, A.D., Algeo, T.J., Anbar, A.D. (2011) Rapid expansion o oceanic anoxia immediately before the end-Permian mass extinction. Proceedings of the National Academy of Sciences 108, 17631-17634.

BUTTERFIELD, N.J. (1997) Ecology and the Proterozoic-Phanerozoic Transition. Paleobiology 23, 247-262. ButTerfield, N.J. (2009) Oxygen, animals and oceanic ventilation: an alternative view. Geobiology 7, 1-7.

CANFiELD, D.E., FARQUHAR, J. (2009) Animal evolution, bioturbation, and the sulfate concentration of the oceans. Proceedings of the National Academy of Sciences USA 106, 8123-8127.

Chen, X., Ling, H.F., Vance, D., Shields-Zhou, G.A., Zhu, M., Poulton, S.W., Och, L.M., JiAnG, S.Y., LI, D., CremoneSe, L., ArCher, C. (2015) Rise to modern levels of ocean oxygenation coincided with the Cambrian radiation of animals. Nature Communications 6, 7142

Chen, X., Romaniello, S.J., Herrmann, A.D., Wasylenki, L.E., Anbar, A.D. (2016) Uranium isotope fractionation during coprecipitation with aragonite and calcite. Geochimica et Cosmochimica Acta 188, 189-207.

Dahl, T.W., Hammarlund, E.U., Anbar, A.D., Bond, D.P.G., Gill, B.C., Gordon, G.W., Knoll, A.H., Nielsen, A.T., Schovsbo, N.H., CAnfield, D.E. (2010) Devonian rise in atmospheric oxygen correlated to the radiations of terrestrial plants and large predatory fish Proceedings of the National Academy of Sciences 107, 17911-17915.

Dahl, T.W., Boyle, R.A., CANField, D.E., Connelly, J.N., Gill, B.C., Lenton, T.M., Bizzarro, M. (2014) Uranium isotopes distinguish two geochemically distinct stages during the later Cambrian SPICE event. Earth and Planetary Science Letters 401, 313-326.

DunK, R.M., MiLLs, R.A., JENKINS, W.J. (2002) A reevaluation of the oceanic uranium budget for the Holocene. Chemical Geology 190, 45-67.

Elrick, M., Polyak, V., Algeo, T.J., Romaniello, S., Asmerom, Y., Herrmann, A.D., Anbar, A.D, ZHAO, L, CHEN, Z-Q, (2016) Global-ocean redox variation during the middle-late Permian through Early Triassic based on uranium isotope and Th/U trends of marine carbonates. Geology, G38585.1.

Gill, B.C., Lyons, T.W., Young, S.A., Kump, L.R., Knoll, A.H., SAltzman, M.R. (2011) Geochemical evidence for widespread euxinia in the later Cambrian ocean. Nature 469, 80-83.

HedGES, J.L., KeIL, R.G. (1995) Sedimentary organic matter preservation: an assessment and speculative synthesis. Marine Chemistry 49, 81-115.

Hou, X.G., Aldridge, R.J., Bergström, J., Siveter, D.J., Siveter, D.J., Feng., X.H. (2004) The Cambrian fossils of Chengjiang, China - the flowering of early animal life. Blackwell Publishing, Malden, Oxford.

IvANTSOV, A.Y. (1990) The first findings of phyllocarida in the lower Cambrian deposits of Yakutia Russian SFSR USSR. Paleontologicheskii Zhurnal, 130-132.
Jin, C., Li, C., Algeo, T.J., Planavsky, N.J., CUi, H., Yang, X., ZhaO, Y., Zhang, X., XIE, S. (2016) A highly redox-heterogeneous ocean in South China during the early Cambrian ( 529-514 Ma): Implications for biota-environment co-evolution. Earth and Planetary Science Letters $441,38-51$

Kendall, B., Komiya, T., Lyons, T.W., Bates, S.M., Gordon, G.W., Romaniello, S.J., Jianc, G., CReaser, R.A., XiaO, S., McFadden, K., Sawaki, Y., Tahata, M., Shu, D., HaN, J., LI, Y., CHU, X., ANBAR, A.D. (2015) Uranium and molybdenum isotope evidence for an episode of widespread ocean oxygenation during the late Ediacaran Period. Geochimica et Cosmochimica Acta 156, 173-193.

Kouchinsky, A., Bengtson, S., Pavlov, V., Runnegar, B., Torssander, P., Young, E., ZIEGLER, K. (2007) Carbon isotope stratigraphy of the Precambrian-Cambrian Sukharikha River section, northwestern Siberian platform. Geological Magazine 144, 1-10.

Kouchinsky, A., Bengtson, S., Runnegar, B., Skovsted, C., Steiner, M., Vendrasco, M. (2012) Chronology of early Cambrian biomineralization. Geological Magazine 149, 221-251.

Lau, K.V., Maher, K., Altiner, D., Kelley, B.M., Kump, L.R., Lehrmann, D.J., Silva-Tamayo, J.C., Weaver, K.L., YU, M., PAYNe, J.L. (2016) Marine anoxia and delayed Earth system recovery after the end-Permian extinction. Proceedings of the National Academy of Science USA $113,2360-2365$.

Lehmann, B., Nägler, T.F., Holland, H.D., Wille, M., MaO, J., Pan, J., MA, D., Dulski, P. (2007) Highly metalliferous carbonaceous shale and Early Cambrian seawater. Geology 35, 403

Lenton, T.M., Boyle, R.A., Poulton, S.W., Shields-Zhou, G.A., Butterfield, N.J. (2014) Co-evolution of eukaryotes and ocean oxygenation in the Neoproterozoic era. Nature Geoscience 7, 257-265.

Logan, G.A., Hayes, J.M., Hieshima, G.B., Summons, R.E. (1995) Terminal Proterozoic reorganization of biogeochemical cycles. Nature 376, 53-56.

Lyons, T.W., ReINHARD, C.T., PlanavSKY, N.J. (2014) The rise of oxygen in Earth's early ocean and atmosphere. Nature 506, 307-315

Maloof, A.C., Porter, S.M., Moore, J.L., Dudas, F.O., Bowring, S.A., Higgins, J.A., Fike, D.A., EDDY, M.P. (2010) The earliest Cambrian record of animals and ocean geochemical change. Geological Society of America Bulletin 122, 1731-1774.

Mangano, M.G., Buatois, L.A. (2014) Decoupling of body-plan diversification and ecological structuring during the Ediacaran-Cambrian transition: evolutionary and geobiological feedbacks. Proceedings of the Royal Society B. Biological Science 281, 20140038

MeYer, K.M., RidgwelL, A., PAYNE, J.L. (2016) The influence of the biological pump on ocean chemistry: implications for long-term trends in marine redox chemistry, the global carbon cycle, and marine animal ecosystems. Geobiology 14, 207-219.

Mills, D.B., CANFIELD, D.E. (2014) Oxygen and animal evolution: Did a rise of atmospheric oxygen "trigger" the origin of animals? Bioessays 36, 1145-1155.

Montoya-Pino, C., Weyer, S., Anbar, A.D., Pross, J., Oschmann, W., van de SchootBRUGGE, B, ARZ, HW. (2010) Global enhancement of ocean anoxia during Oceanic Anoxic Event 2: A quantitative approach using U isotopes. Geology 38, 315-318.

MORFORD, J.L., EMERSON, S. (1999) The geochemistry of redox sensitive trace metals in sediments. Geochimica Et Cosmochimica Acta 63, 1735-1750.

Noordmann, J., Weyer, S., GeorG, R.B., Jons, S., Sharma, M. (2016) 238U/235U isotope ratios of crustal material, rivers and products of hydrothermal alteration: new insights on the oceanic $\mathrm{U}$ isotope mass balance. Isotopes in Environmental Health Studies 52, 141-163.

Perrier, V., Williams, M., Siveter, D.J. (2015) The fossil record and palaeoenvironmental significance of marine arthropod zooplankton. Earth-Science Reviews 146, 146-162. 
SperLing, E.A., Frieder, C.A., RAmAn, A.V., Girguis, P.R., Levin, L.A., KNOLL, A.H. (2013) Oxygen, ecology, and the Cambrian radiation of animals. Proceedings of the National Academy
of Sciences 110, 13446-13451.

Stein, M., Peel, J., Siveter, D., Williams, M. (2009) Isoxys (Arthropoda) with preserved sof anatomy from the Sirius Passet Lagerstätte, lower Cambrian of North Greenland. Lethaia 43, $258-265$.

TISSOT, F.L.H., DAUPHAS, N. (2015) Uranium isotopic compositions of the crust and ocean: Age corrections, U budget and global extent of modern anoxia. Geochimica et Cosmochimica Acto $167,113-143$.

Vinther, J., STEIN, M., LONGRICH, N.R., HARPER, D.A. (2014) A suspension-feeding anomalocarid from the Early Cambrian. Nature 507, 496-499.

Wen, H., Carignan, J., Zhang, Y., Fan, H., Cloquet, C., LiU, S. (2011) Molybdenum isotopic records across the Precambrian-Cambrian boundary. Geology 39, 775-778.

Wen, H., Fan, H., Zhang, Y., Cloquet, C., CARIGnan, J. (2015) Reconstruction of early Cambrian ocean chemistry from Mo isotopes. Geochimica et Cosmochimica Acta 164, 1-16.

Weyer, S., Anbar, A.D., Gerdes, A., Gordon, G.W., Algeo, T.J., Boyle, E.A. (2008) Natural fractionation of 238U/235U. Geochimica et Cosmochimica Acta 72, 345-359.

Wille, M., NAgler, T.F., LehmanN, B., Schroder, S., Kramers, J.D. (2008) Hydrogen sulphide release to surface waters at the Precambrian/Cambrian boundary. Nature 453, 767-769.

Xu, L., Lehmann, B., MaO, J., Nägler, T.F., Neubert, N., Böttcher, M.E., Escher, P. (2012) Mo isotope and trace element patterns of Lower Cambrian black shales in South China: Multiproxy constraints on the paleoenvironment. Chemical Geology 318-319, 45-59.

ZHURAVLEV, A., WOOD, R. (1996) Anoxia as the cause of the mid-Early Cambrian (Botomian) extinction event. Geology 24, 311-314. 